\title{
БОЖАНСКА СИЛА ЧАСНОГ КРСТА ГОСПОДЫЕГ И ЊЕГОВ ОДСЈАЈ У УМЕТНОСТИ ДРВОРЕЗБАРСТВА
}

\author{
Јован Ћеранић*
}

Покрајнски Завод за заштиту споменика културе, Петроварадин

Сажетак: Крст као знак и симбол памте палеолит, неолит, гвоздено доба и микенска култура. Казна подизања на крст позната је у атичко време али и десетинама векова пре Христа у Египту. У почетку овакакв крст је једноставнијег облика сачињен само од вертикале. Сложенији крст од два дрвета, стих соттіsа, вертикале и хоризонтале појављује се у време непосредно пред Христов долазаку свет и његовог страдања на крсту. Распећем Господа Исуса Хрста крст добија нови смисао није више средство понижења, мучења и смртне казне него постаје оруђе победе над грехом и смрћу, снага и сила православних хришћана у све векове до свршетка света. Крст као појам и симбол присутан је у иркви од првих векова хришћанства. Проучвање крстова започели су у XIX веку археолози, историчари уметности и византолози. Током XX века истраживања су углавном континуирано настављена, а корак даље је конституисање нове науке - ставрографије. Запажена је ьегова широка употребна функиија, богата типологија и разноликост уметничких облика. Иконографија крста се формира од VI века, а најразвијеније представе сачуване су на дрворезбареним крстовима светогорских радионица XVI, XVII и XVIII века. Дрворезбарство једно од најстаријих и најраспрострањенијих уметности је данас у великој мери запостављено и потиснуто савременом машинском израдом ирквеног мобилијара и других предмета ирквене уметности.

Кључне речи: крст, символ, ирквена уметност, иконографија, дрворезбарство.

\section{Крст појам, знак, символ}

Дрво некада донесе горчину у Едем, а дрво Крста слатким животом прочвета. Јер Адам појевши (забрањени плод) у трулежност пропаде а ми, наслађујући се Телом Христовим,

*ел.пошта: jovanceranic@gmail.com 
живимо и светотајински се обожујемо, примајући вечно иүарство Божије. ${ }^{l}$

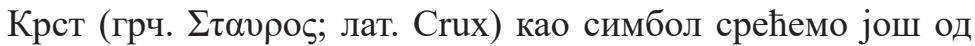
епохе палеолита, 15 векова пре Христа. Тада кукасти крст crux cammata представља ознаку летњег солстација и симбол плодности и здравља. Неолит памти крст у култури Вучедола пре 7000 година, из гвозденог доба крст је сачуван код Илиpa, микенска култура нам оставља крст пронађен на острвима Егејског мора. У античко време крст означава казну, тзв. ропско мучење (servile supplicem), за оне који су се огрешили о римске законе. Осуђеник је на крсту трпео како физички бол тако и велико понижење. Оваква врста казне, подизања на крст, позната је и раније Египћанима 17 векова пре Христа. Дрво је тада било равно, пободено усправно без хоризонтале simplex crux. Сложенији крст од два дрвета, crux commisa, појављује се у време највеће моћи али и највеће неправде римских власти. Састојао се од вертикале и хоризонтале изнад главе, где је постављена дрвена табла на коју је писано име осуђеног и кривица. На овакав крст осуђеник није као раније везиван, већ је прикиван. Остављан је без воде, а често су му ломљене кости ногу како би тиме убрзали смрт. На оваквом крсту разапет је Господ Исус Христос. За Грке Крст је казна, а за Јудеје саблазан. За хришћане од тренутка распећа и Васкрсења Христа Бога Крст добија потпуно нови смисао, Његовом крсном смрћу крст постаје оруђе не страдања као до тада, већ оруђе победе греха и смрти, спасоносна животворна сила и симбол Другог Доласка Христовог у Сили и Слави. Крстом ми Хришћани живимо, њиме се у Христа облачимо и њиме побеђујемо.

Крст Твој, Господе, отвори рај роду људском; и избавивши се од смртности, ми певамо Тебе, распетог телом Бога намег, помилуј нас. ${ }^{2}$

\footnotetext{
${ }^{1}$ Вечерња служба Крстополоне недеље, стихира Јутрења у среду (4. Глас), катизма.

2 Уторник, вече, на стихов. стихире; Глас 6, Октоих.
} 
Крст се појављује још у Старом завету, а онај који је дрветом преварио праоца нашег Адама изигран је на Крсту, дрветом је дрво требало да буде исцељено. Мојсије је симболизаовао Христа на Крсту када је раширио руке к небу да би створио слику Крста и натерао у бекство тирана Амалика, а патријарх Јаков је унапред предсказао Крст Христов када је благосиљао своје унуке, ставивши им на главу укрштене руке. Начинивши штапом пред собом знак Крста, Мојсије отвори Црвено море Израиљу који га пређе као по сувом.

Признањем хришћанства за државну веру од стране Светог цара Константина 313. године хришћани добијају слободу исповедања вере, а казна разапињања на крсту је укинута 21. марта 315. године. ${ }^{3}$ Од тада број хришћана непрестано расте, а њихово слободно изаражавање вере доводи до потребе већег јавног окупљања. Тако добијају простор за своје храмове које прилагођавају својим богослужбеним потребама и украшавају хришћанским симболима и представама. Прве појаве су у облику сидра или Ү. Најстарија сачувана представа крста на рељефу из Палмире је Старограф из 134. године. Најстарије преставе на новцу потичу из 40-тих година IV века. На застави из времена Светог цара Константина ношеној на Милвијском мосту 312. године је представа Крста (Христов монограм). ${ }^{4}$ Представа крста присутна је у катакомбама, ${ }^{5}$ баптистеријумима - хришћанским крстионицама и импозантим мозаицима Равенских цркава ${ }^{6}$, као и на богослужбеним и личним предме-

${ }^{3}$ Велики православни богословски енциклопедијски речник, Том 2 (Нови Сад: Православна реч , 2000), 1058.

4 Лазар Мирковић, Иконографске студије (Нови Сад: Матица српска, 1974), 7-9; Горан Јанићијевић, Хришћанска уметност и античке парадигме (Београд: Академија Срспске православне цркве за уметности и консервацију, 2012), 102-112.

5 Домицилина катакомба, Светог Петра и Марцелијана, Калистова Катакомба (у средишту Крст у кргу). О томе види: Фридрих Герке, Касна антика $и$ рано хришћанство ( Нови Сад: Братство и јединство, 1973).

${ }^{6}$ Св. Аполинара Новог, Св. Аполинара у Луци, Св. Витала, маузолеј Гале Плацидије. О томе види: Mario Mazzeti, La Basilica di Sant Apollinare in Classe (Cittta del Vaticano: Pontificio Istituto di Archeologia, 1954); Giuseppe 
тима хришћана. Код нас најстарије представе крста Господњег налазимо на источном зиду старохришћанске гробнице у Нишу, изнад улазних врата, где је насликан „Константинов” монограм са апокалиптичним словима A W (Отк. 1,8; 21,6; $22,13)$ окружен венцем од палминих грана - који има символично значење награде за победу, а испод монограма излази на обе стране по једна палмина грана. На западном зиду је такође представа Христовог монограма. Шта се садржи у Крсту и шта садржи Крст? Вертикала и хоризонтала : Божанско и Човечанско, пролазно преображено у вечно. Љуби Господа Бога својега свим срием својим, и свом душом својом и свом мисли својом. Ово је прва и највећа заповест. А друга као и ова: Љуби ближюега својега као самога себе. О овима двјема заповестима виси сав закон и пророции (Мт. 22,37; Лев. 6,5). ${ }^{7}$ Раширених руку човек чини крст, а тачка сусретања вертикале и хоризонтале јесте срце човеково. Сврх свега што се чува чувај срие своје јер из њега излази живот (Пр. 4,23). Ако је чиста тачка сусретања - место где се сусрећу Бог и човек, место измирења, смирења, тиховања, молитве, место вере, наде љубави, истрајности, место Живота - онда је целокупан живот чист. ${ }^{8}$ Круг је симбол савршенства, рајског насеља, а Крст у

Bovini, Mosaici de S. Apollinare Nuovo di Ravenna: Il Ciclo Cristologico (Firenze: Arnaud, 1958); Мирковић, Иконографске студије, 45-161; Војислав Кораћ и Марица Шупут, Архитектура византијског света (Београд: Завод за уџбенике, 2005), 60; Cyril Mango, Architettura Bizantina (Milano: Mondadori Electa, 1978), 138-140.

${ }^{7}$ Као што крст има вертикалну осу која говори о односу човека према Богу и хоризонталну која говори о односу човека према ближњем, тако се у првим од 10 заповести датих Мојсију говори о љубави према Богу, а у другима о љубави према ближњем. И две Христове заповести тако су подељене.

${ }^{8}$ Горњи крак означава врх наде, доњи веру у чврсте темеље: ширина је милосрђе, а висина усправсност до краја живота. Крст је симбол личне одлуке, често смо током живота суочени са не малим бројем раскрсница, уствари цео живот је избор раскрсница, и така слободно бирамо пут којим ћемо поћи, бирамо наш Крст. Дакле крст је слободан избор, кретање и живот, а не безличан закон (јудаизам) и неизмењива судбина (паганизам), кретање у круг (будизам). Крст такође симболизује наду да ће се сви људи (са све четири стране света) окупити у једном средишту у општој љубави. 
кругу симбол пуноће живота у Христу. Празно срце Бога живога указује на празан ум, помрачени разум, незнабоштво и непознавање Христа, које у практичном животу редовно има свој крај неморалног живота. Предуслов за истински живот врлине је стицање добре савести и унутрашњег мира а то се постиже једино и само уз светотајински и световрлински живот у Цркви. ${ }^{9}$ Сви који се у Христа Крштавају у Христа се и облаче, и призвани су да кроз живљење у складу са заповестима Христовим, у светотаинској заједници Цркве, стекну Христов ум, Христову Нарав, а та Нарав јесте нарав Крста, жртве, самилости, опраштања, несебичности.

Крстом Твојим Христе, постаде једно стадо од Анђела и људи, и једна Црква - небо и земьа весели се; Господе, слава Теби. ${ }^{10}$

\section{Типологија Крстова и њихова употребна функција у Цркви}

Проучвање крстова започели су у XIX веку археолози, историчари уметности и византолози. Током XX века истраживања су углавном континуирано настављена, а корак даље је конституисање нове науке - ставрографије. Први значајни објављени радови су се углавном односили на крст реликвијар. Помак је направио, почетком XX века, руски научник П. Кондаков који је у свом истраживању истакао важност на-

Круг који описујемо око Крста је симбол Света. Види: Велики православни богословски енциклопедијски речник, 1060. О Крсту у кругу види: Оливер Томић, Геометријски симболизам у примордијалној традииији (Београд: Математичи институт САНУ, 2021). //miteam.mi.sanu.ac.rs/asset/ fKxCZkJ5efhtrwCbT аудио снимак (приступљено 20. 9. 2021).

9 Драгомир Сандо, Богослужење као основа образовања и васпитања у иркви (Београд: Глобосино 2009), 43; Срце је у патристичкој подвижничкој антропологији и гносеологији не само сазнајни орган, него и средиште целокупног човековог живота. „Имати срца ка Господу”. Види: Јован Пурић, Богословље и педагогика Св. Јована Златоустог, Књ. 3 (Београд: Верско добротворно старатељство Архиепископије београдско-карловачке, 2011), 93-96, 112.

${ }^{10}$ Петак друге недеље по Васкрсу, јутрење, на хвалитех стихире. 
грудних крстова који су настали у радионицама Палестине и Сирије и другим деловима хришћанског истока. Указао да су иконографски доста верно ослоњени на сцене монументалне уметности најранијих цркава те расветљавају међусобну повезаност, континуитет и смисао црквене уметности тога времена па и до данас. Његов настављач је К. Мијатев, који је већ 1922. године објавио „палестинске крстове” из Народног музеја у Софији и тако заинтересовао будуће истраживаче, међу њима М. Барањи-Обершал, која проучава појаву византијских крстова у Мађарској. Истом темом бавила се и Ж. Ловаг. ${ }^{11}$ Национална историја уметности, изузев неколико усамљених примера, све до половине XX века, не бележи темељно бављење крстовима, њиховом појавом и садржајем. Теми Крста посвећују се озбиљније Светозар Радојчић ${ }^{12}$, Лазар Мирковић, Бојана Радојковић ${ }^{13}$ и други.

Један од првих опсежнијих радова дала је Гордана Маријановић-Вујовић, предано обрадивши одабране крстове Збирке Народног Музеја. ${ }^{14}$ Душан Миловановић је својим радом на истраживању крстова збирке Музеја примењене уметности дао велики допринос проучавању крстова. ${ }^{15}$ Такође треба поменути да је знатан број археолошких или уметничких изложби међу својим експонатима имао репродукцију или ориганалан крст један или више, који су том приликом и обрађени. ${ }^{16}$

${ }^{11}$ Гордана Марјановић-Вујовић, Крстови од VI- ХІІ века из збирке Народног Музеја (Београд: Народни музеј, 1977), 5-6.

12 Светозар Радојчић, „Бронзани крстови - реликвијари из раног средњег века у београдским збиркама" у Одабрани чланции и студије: 1933-1978 (Београд: „Југославија”; Нови Сад: Матица Српска 1982), 53-58.

${ }^{13}$ Бојана Радојковић, Српско златарство XVI и XVII века (Нови Сад: Матица српска, 1966), 7-75; Бојана Радојковић, Уметничка обрада метала (Београд: Музеј примењене уметности, 1953), 5-21.

${ }^{14}$ Марјановић-Вујовић, Крстови,5-6.

15 Душан Миловановић, Крстови: (од 5. века до 1993. године): типологија и историјско стилски развој збирке крстова Музеја примењене уметности из Београда (Београд: Музеј примењене уметности, 1993).

${ }^{16}$ Лазар Трифуновић и Ђурђе Бошковић, Cmapa култура у Ђердаny: Anciennes cultures du Derdap (Београд: Галерија Српске академије наука и уметности, 
Крстови су проучавани у овиру истраживања манастирских ризница, од којих посебно место заузима рад историчарке уметности Мирјане Шакоте. ${ }^{17}$

Када је реч о облику крста према досадашњим проучавањима у научним круговима најзаступљенија је следећа подела: 1 . вертикално дрво (17.000 година с.е); 2. Крст Светог Андрије, у облику слова X; 3. крст у облику слова T; 4. Латински крсткрст код кога је дужа вертикала крста, а пресек крста није на средини вертикале већ је нешто изнад ње; 5. Грчки крст - са једнаким крацима крста; 6. Руски или патријаршијски крст са осам кракова; 7. Тетраграматион - крст окренут наопачке (крста Светог. Ап. Петра). Поједине приказе је на први поглед понекад теже распознати:: Константинов монограм, четворолатични, детелинасти, сидролики, чапорасти, јерусалимски. ${ }^{18}$ Посебан тип крста украшен драгим камењем crux gemmata утврдио је цар Константин, симболизовао је тријумф хришћанства и био је постављен у цркви на Голготи. Данас су најчешће у употреби Грчки и Латински крст, не искључују један другог и подједнако су у употреби у католичкој и православној цркви.

Најчешћи типови крстова који се користе у хришћанској цркви од раног средњег века до данас:

1. Реликвијари су крстови који су у себи чували реликвије светитеља. Прављени су од бронзе или неког другог племенитог метала. Састоје се из два једнака, одвојено ливена дела, која су се спајала помоћу једне алке на аверсној страни вертикалних кракова и по две на реверсној страни у виду шарнира. Средишњи део чува реликвију. Ако је у њему честица Часног крста , онда се назива ставротека; ако је честица моштију светитеља, онда је крст кивот. Над шарниром се налазила масивна алка кроз коју је пролазио ланац и тако се крст носио око врата. ${ }^{19}$

1969), 7-210.

${ }^{17}$ Мирјана Шакота, Ризнице манастира у Србији (Нови Сад : Платонеум, 2017).

18 Велики православни богословски енциклопедијски речник, 1059; Миловановић, Крстови, 9-10.

${ }^{19}$ Маријановић-Вујовић, Крстови, 12-16, 47-49; Миловановић, Крстови, 19. 
2. Нагрудни крстови или енколпиони - који се преко металног ланца или врпце неког другог материјала носе на грудима. Код ових крстова разликују се предња аверсна и задња реверсна страна. Ови крстови су углавном уједначеног облика и димензија. Већином су облика латинског крста, а данас све чешће запажамо појаву расцветалог крста. Најчешће димензије су $7 \times 3,5$ и 7x $4 \mathrm{~cm}$. Највећи су око $10 \times 5,6$ најмањи $2,8 \times 1,5 \mathrm{~cm} .^{20}$

3. Нагрудни крстови-привесци имају углавном уједначен облик латинског или грчког крста, једноделни су величине око $3 \times 4 \mathrm{~cm} .{ }^{21}$ Нису чували реликвије, али су били стална заштита хришћанина који га носи. Већином су од бронзе, ређе од олова, сребра или злата, изузетно ретко од стеатита и керамике. Представа Распећа је као и код крстова реликвијара мање или више сложена. ${ }^{22}$ Од времена цара Константина сваки ходочасник добијао је на дар крст. Огромна количина крстова тако стиже из Палестине у друге крајеве света, Русију и на Балкан, где се убрзо након тога отварају радионице. ${ }^{23}$

4. Процесиони - литијски крстови састоје се из два дела: горњег крста и усадника који је по правилу у облику копља. Израђени су од бронзе, олова или другог метала, а могу бити и дрвени. Димензије варирају од око 27х12, до 54х25 cm. Крст је најчешће латинског облика са завршетком у светогорском тролисту (расцветали крст) и његовим варијантама. ${ }^{24}$ Најстарији су код нас из рановизантијског периода, из VI века, из Цркве светог Јована у околине Пирота, као и оловни крст нађен у Костолцу, данас оба у збирци Народног Музеја.

5. Крстови су коришћени и као пломбе. Малих димензија, око $3 \times 2 \mathrm{~cm}$, метални су и често облика крста Светог Петра; оба

\footnotetext{
${ }^{20}$ Маријановић-Вујовић, Крстови, 12-16.

${ }^{21}$ Ibid.

${ }^{22}$ Ibid, 17.

${ }^{23}$ Миловановић, Крстови, 12-13.

${ }^{24}$ Марјановић-Вујовић, Крстови, 59.
} 
хоризонтала и доњи крак једнаки су док је горњи дужи и на њему је канал за низање. ${ }^{25}$

6. Крстови који су саставни делови носача полијелеја или кандила. Малих су димензија, најчешће од метала. Велики број ових крстова рановизантијског периода је нађен у Нишу, Костолцу (Виминацијуму-главном граду римске провинције Горње Мезије)

7. Крстови привесци су они који су у виду привеска закачињани на процесијске крстове и заједно са њима ношени. Прављени су од метала, димензија су знатно мањих од процесијских, око $6 \times 5 \mathrm{~cm}$. Овакве и сличне крстове су верници даривали цркви. ${ }^{26}$

8. Крст оковани - од дрвета, рога или другог материјала, који је резан, а затим и окован металом. При резњу окова примењиване су најразличитије технике украшавања, а најчешће ливење „на пробој”, ковање, резање. Репрезентативни окови се још увек украшавају гравирањем, филиграном и гранулацијом, стаклом, емајлом, полудрагим и драгим каменом, а ретко и бисерима.

9. Крстови проскорници - уместо стопе имају квадратни печат за остваривање отиска на славском колачу или проскорници. Садржи Хрисотве иницијале ИС ХС НИ КА. Крст изнад печата представља развијени часни крст у руској варијанти.

10. Крст Престони - јесте крст који стоји на часној трпези или престолу у олтару цркве. С великом пажњом изведени, ови крстови су дрвени и оковани племенитим металом, филиграном, украшени су драгим камењем. Постављени су на стопу која често по средини има јабуку или чвор и који се ослања на надвишену и богато украшену стопу.

11. Ручни или целивајући крст или како се назива још и водички тј. за свећење водице је по много чему обликом, иконографијом и донекле величином близак реликвијару. Такође је сам могао бити реликвијар или кивот, јер је у себи могао

\footnotetext{
${ }^{25}$ Ibid, 60-61.

${ }^{26}$ Ibid, 27.
} 
имати свете честице. Обликом може бити грчки, расцветали (разлистали), латински или њихова варијанта. Има примера да су хоризонтални краци крста нешто краћи што минимално ремети склад ( крст бр.34. из Ризнице Бање код Прибоја). или да је вертикални крак крста ужи од хоризонталног ( крст бр.42. Ризница манастира Бање код Прибоја). ${ }^{27}$ Ручни крстови се састоје из два дела горњег крста и дршке која често има јабуку, украшена је флоралним или геометријским орнаментом. Израђени су од дрвета, бронзе, олова или другог метала. Димензије варирају од око 27 х 12 до 54 х $25 \mathrm{~cm}$. Рељефне представе су и на аверсу и на реверсу, тј. има два лица. Често су оковани - најчешће сребром или позлатом, украшава се свим техникама дораде. Најлепша колекција до данас сачувана код нас је у ризници манастира Бање код Прибоја. Право ношења ручног крста имају Епископи а такође и свештеници у посебним приликама током вршења Светих Тајни ( крштења, венчања, миропомазања...), приликом освећења воде и када њиме благосиљају верни народ.

Током досадашњих археолошких истраживања поред крстова и калупи за ливење крстова угледали светлост дана. Један је нађен на локалитету Велики Градац код Доњег Милановца. Предпоставља се да потичеиз X или XI века. ${ }^{28}$

\section{Иконографија крстова}

Појава крстова са сценом Распећа на аверсној и Богородицом орантом на реверсној страни доводи се у везу са Палестином и Јерусалимом, где је на месту страдања Христовог Света царица Јелена пронашла Христов Часни Крст (Воздвижење Часног Крста-Крстовдан 27/14 септембар) где је и Црква подигнута.

Крстови који су настајали у Јерусалиму су били намењени ходочасницима. Израђивани су од бронзе, у плитком рељефу, могли су их радити и не тако вешти мајстори. Најбољи мајстори радили за црквене и државне великодостојнике крстове од

${ }^{27}$ Мирјана Шакота, Ризница Манастира Бање код Прибоја (Нови Сад: Платонеум, 2018), 106-107.

${ }^{28}$ Миловановић, Крстови, 19. 
злата, сребра и другог племенитог материјала у плитком рељефу. Често су они од злата украшавани драгим камењем, понекад бисерима и филиграну. Сцене Распећа из зидног живописа врло брзо су пренете на крстове. Иконографија представе Распећа се креће од најједноставнијих, где је приказан сам Господ Иусу Христос, па до оних са потпуно развијеним приказима из јеванђеља. Чест пратилац развијених сцена је текст јеванђеља који говори о Распећу или су то само иницијали Христовог имена. Низ примера оваквих крстова налазимо у збирци Народног музеја, који су заслугом Гордане Марјановић-Вујовић детаљно описани. ${ }^{29}$ Потребно је истаћи да је на готово свим крстовима ове збирке из периода од VI до XII века Христос обучен у дугу хаљину без рукава (колобијум), са различито обликованим изрезом око врата. Мање је примера где је колобијум дугих рукава или где преко њега пада огртач од грубог материјала, дужи од њега. Ређи су примери где је Христос огрунут кратком перизомом, а до појаса наг. Има примера где је дат у одећи која је нешто између перизоме и колобијума. Христове ноге су једна до друге, најчешће постављене на супеданеуму. Глава Христова је по правилу нагнута на десну страну и обавијена крстастим нимбом. Горњи вертикални крак крста могао је бити завршен табулом. Код сложенијих, на њој је исписиван Христов монограм, а понегде је само слово X, док се код поједностављених само приказује пластично наглашен крст. Представе сунца и месеца нису обавезни пратиоци Распећа. Реверси крстова реликвијара најчешће у средишту имају представе Богородице Оранте, док су на краковима представе јеванђелиста, светитеља у медаљонима или без њих. Чест је и мотив палме. Овакве представе су карактеристичне не само за Србију већ и за околне земље у периоду од VI до XII века. ${ }^{30}$ Што се обраде тиче, најчешћа је рељефна, али свакако има примера и урезивања, нарочито код крстова слабијег квалитета и израде. Понегде је тај цртеж потпуно шематизован. Распеће на аверсу и Пресвета Богородица на реверсној страни није обавезно присутно

${ }^{29}$ Маријановић-Вујовић, Крстови, 12-13.

${ }^{30}$ Helen C. Evans and William D. Wixom, eds., The Glory of Byzantium Art and culture of the Middle Byzantian era A.D.843- 1261 (New York :The Metropolitan 
на крстовима реликвијарима. Постоје и такви крстови који на обе стране имају представе Светитеља са рукама подигнутим у молитвеном ставу. Не ретко се појављују удвојени натписи када је приказан само један светитељ. ${ }^{31}$ Претпоставља се да су ове крстове носили војници-ратници како би их свети ратници штитили у биткама. Након процвата хришћанске уметности у доба царева Константина и Јустинијана, време иконоборства оставља свој траг и у иконографији крста. Враћају се симболи, геометријске форме и натписи имена Господа, Богородице и светитеља. Након победе православних над иконоборцима нагло цвета развој иконографије крста, она се тада коначно успоставља. ${ }^{32}$ Крстови настали након иконоборских распри, у Русији и шире губе своје првобитно значење и сада у себи синтетизују сва значења иконе-крста, која је поред осталог код за преношење Христове љубави верноме и повратно. Каснији векови развијају схеме на аверсној страни и доносе представе Господњих и Богородичиних Великих празника, најчешће Крштење, Вазнесење, Благовести, док је на реверсној страни нека од представа чудотворних икона Богородице (Владимирска, Не плачи мене мати, Казанска, Тихвинска, Тројеручица). ${ }^{33}$ Током позног средњег века често се појављује представа Крштења у средишту на реверсној страни, што ћемо касније покушати да објаснимо, а око ње Велики празници. Најразвијеније представе јављају се у XVI, XVII и XVIII веку на дрворезним крстовима, посебно онима који се режу у светогорским ради-

Museum of Art, 1997 ), 169.

${ }^{31}$ Маријанови-Вујовић, Крстови, 15.

${ }^{32}$ Од тада се као по правилу на аверсној страни представља Распеће, а на реверсној Богородица Оранта, или понекад са прекрштеним рукама што означава предавање вољи Божијој. У то време вештином уметник успева да само са неколико потеза дефинише читав приказ распетог тела Христа: Руке су постављене хоризонтално без прегиба; уобичајено глава је нагнута на десно раме; испод може бити текст јванђеља „Ето ти Сина» или друго. Постоје сунце и месец. Са страна су Свети Јован и Богомајка, а на крајевима у медаљонима су јванђелисти. Све фигуре су сигниране. Све што смо навели: колобијум, речи упућене Богородици - комплтна композициона схема, облик крста (шири на краковима крста) одлике су сиријско-палестинског крста.

${ }^{33}$ Миловановић, Крстови, 23. 
оницама. Тада се не ретко на крсту појављују свих 12 Великих празника. Такође се приказују уз јеванђелисте и одабрани светитељи и светитељке посебно или у пару, као и пророци, а све је најчешће уоквирено биоморфним, зооморфним или геометријским орнаментом или су пак смештени у оквир налик на шаторе Господње. Израда најрепрезантивнијих примера крстова који се данас чувају у Музеју примењене уметности, Народном музеју и манастирским ризница била је поверена изузетним мајсторима, јер ово су веома мале површине тако да су морали вршити сублимацију и стилизацију и успевали су да постигну чистоту ликовног израза. Врло често су на крстовима исписивани текстови молитве, делови црквених песама, тропари и кондаци, док су на дршкама писани подаци када је крст израђен, за кога и ко га дарује. Пример оваквог крста је крст мирополита Дионисија из 1568 . године. ${ }^{34}$

Почев од XVIII века, под руско-украјнским утицајем, на крстовима, престоним иконама и иконостасима цркава Карловачке митрополије наилазимо на представе Бога Оца у људском обличију. Данас их најчешће видимо на Целивајућим крстовима. Оваква и сличне погрешне појаве у савременој црквеној уметности се не смеју занемаривати. Потребно их је образложити аргументима који се заснивају на Светом Писму, Светом предању и Васељенским саборима.

„Нико неће видети лице моје и жив остати” (Изл. 33,20) „Бога нико није видио никада, Јединородни Син Који је у наручју Оиа, Он Га објави”. (Јн. 1, 18)

И заиста, ако бисмо ми правили слику (икону) невидљивог Бога Оца, грешили бисмо, јер је немогуће изобразити оно што је бестелесно и без облика, невидљиво и неописиво. Међутим Бога Христа, Сина Божијег који се јавио телесно на земљи можемо сликати, како нам и текст Јеванђеља каже и тиме добити разјашњење односа образа и Праобраза, архетипа, изображења и изображаваног. ${ }^{35}$

\footnotetext{
${ }^{34}$ Шакота, Ризница манастира Бање, 97-99.

35 Јован Дамаскин Свети, „Апологетска слова против опадача Светих Ико-
} 


\section{Место дрворезбарства и мајстора дрворезбара у црквеној уметности}

Дрворезбарство је једна од најстаријих и најраспрострањенијих уметности. Од раних представа Артемиде Ефеске, Египатске скулптуре, преко средњовековне уметноси и даље до данас и прсутно је код свих народа. ${ }^{36}$ Развијено дрворезбарство постоји код старих Словена већ у VI веку. На основу очуваних фибула стиче се утисак да Словени не само режу и украшавају предмете од дрвета већ им посвећују изузетну пажњу и тако остварују истинска уметничка дела. ${ }^{37}$ Подаци о Словенском дуборезу након прихватања хришћанства су изузетно оскудни. Постоји само један податак о употреби дубореза и дрвореза при украшавању цркава на православном словенском Балкану, али на жалост и он није потпуно прецизан. Јован Егзарх, описујући цркву коју је цар Симеон подигао у Преславу, каже само - ... и иееккви издобрани безгода каменїемь дервомь и шаромь из(н)утри же мраморомь и мђдіюю сребромь и златомъ. Дрворезбарство своју примену почев од средњег века, затим у време турске власти и каснијој уметности новијег доба до данас налази у изради крстова, иконостаса, ${ }^{38}$ дуборезних икона, ${ }^{39}$ врата, ${ }^{40}$ прозора, саркофага, ${ }^{41}$ црквених сасуда, а не ретко

на", у Седми васељенски сабор његов одјек у ирквеној уметности: одабрана документа, ур. Радомир Поповић (Београд: Академија Срспске православне цркве за уметности и консервацију, 2012), 61-68; Ирина Языкова, Богословие иконы (Москва: Общедоступный Православный Университет, 1995).

${ }^{36}$ Мирјана Ћоровић-Љубинковић, Средњевековни дуборез у источним областима Југославије (Београд: Научно дело, 1965), 1.

37 Joyef Strzygowski, O razvitku starohrvatske umetnosti: prilog otkriću sjeverno-evropske umjetnosti (Zagreb: Matica hrvatska,1927), 120-125; ЋоровићЉубинковић, Средњевековни дуборез, 2-6. У време покрштавања IX-X век, палате у Бугарској су украшене фигурама резаним у дрвету. Такође постоје подаци да је у Русији XII века дрворезбарство било знатно развијено. Међутим од старе Руске скулптуре у дрвету није ништа очувано.

${ }^{38}$ Ћоровић-Љубинковић, Средњевековни дуборез, 8- 37.

${ }^{39}$ Ibid, 38-41.

${ }^{40} \mathrm{Ibid}, 42-54$.

${ }^{41}$ Ibid, 54-58. 
у новијој уметности и целокупног црквеног намештаја. Када је реч о дуборезачким школама њихову појаву и развој можемо пратити од обнове Пећке Патријаршије. Од тада дуборез се нагло развија и готово нема Цркве у којој није коришће, а велики број је очуван. Највећи утицај је имала Пећка школа која је најдуже и трајала, два века. ${ }^{42}$ У Македонији је постојала засебна група дела, у широј околини Прилепа. ${ }^{43}$ Једна група дуборезних дела везана је за Светогорску дуборезачку школу. ${ }^{44}$ Међутим, како је већ уочено, велики број дуборезнх дела не припада ни једној од поменутих школа већ показују разне утицаје. ${ }^{45}$ Неки су настали под утицајем рада у металу, друга се везују за декоративну пластику у камену, трећа су се инспирисала сликаним орнаментима, нека су резана и под утицајем текстилних мотива. У многобројним очуваним радовима има дела стварне вредности, понегде и изванредних примерака, али врло често су то осредња дела мајстора који се ослањају на своје узоре а понекад их и поновљају у великој мери. Има примера да спонтаности и непосредност у креацији дају већу уметничку вредност делу, али не ретко су то само занатске творевине. ${ }^{46}$

Турски период је обележен дрворезбарством у плитком рељефу најчешће орнаменталних решења, док је каснији период доносио све пластичнија и реалистичнија решења да би већ крајем XVII века рељеф постао дубок а површине педантно обрађене. То је време када предњаче флорални мотиви у односу на зооморфне и геометријске. У Пећкој и Светогорској школи они ће бити не само преовлађујући већ врло често и једини. Међутим једино што је спречавало да дуборез добије пуну изражајност је позлаћивање које је у Србији врхунац примене доживело током XVIII века, а које је и данас у великој мери присутно. $^{47}$

\footnotetext{
${ }^{42}$ Ibid, 90-113.

${ }^{43}$ О Прилепско-слепчанској дуборезачкој школи: Ibid, 64-89.

${ }^{44}$ Ibid, 114-121.

${ }^{45}$ Ibid, 122-134.

46 Ibid, 63.

${ }^{47}$ Ibid, 139-140; Бранка Кулић, Новосадске дрворезбарске радионице (Нови
} 
Према познатим и доступним подацима мајстори дрворезбари - се први пут под сличним именом помињу код патријарха Пајсеја средином XVII века, када их он назива рукоделци. Једини који су имали своје име су мајстори за прављење крстова крстар, или крсторезац. Средњовековни мајстори дуборесци потпуно су нам непознати. Први познати уметници херцеговачки митрополит Антоније, касније српски патријарх, и Лонгин - јављају се у последњој четвртини XVI века. Антоније је био резбар и сликар, што сазнајемо из његовог потписа на дверима у Пећи.

Од средњег века често је један уметник познавао више грана уметности: сликарство, позлатарство, дуборез, На крају XVIII века помиње се Хаџи Рувим који је сликар и дрворезбар - искусни крсторезац како је себе називао. ${ }^{48}$ Са друге стране су постојали и мајстори уско специјализовани само за један посао. У нашим манастирским повељама дрводеље се помињу уз остале занатлије седларе, столаре, шавце, ливце, грнчаре, златаре.

Дуборезни мајстори су први у нашој уметности прихватили изразитије нова решења - из западног стварања, док ће градитељи и сликари то урадити знатно касније. У току XVII века многе новине у Србију долазе са Свете Горе. Тамо су их донели мајстори Крићани. Руски утицај јавиће се знатно касније, и то на ограниченом простору у пећко-морачком стварању, преко Митрофановића који га је донео из Свете Горе или преузео од Лонгина. Дубоки Руско-украјнски утицај продреће у Србију од треће деценије XVIII века почев од теритеорије Карловачке Митрополије где у оквиру новосадских дрворезбарских радионица делује знатан број уметника дрворезбарара ${ }^{49}$

Током XX века до данас у Србији примећујемо стагнирање црквене уметности дрворезбарства изузев повремених појављивања талентованих појединаца чији замах, без подршке, не досеже далеко. Поред не малог броја уметника и

Сад: Галерија Матице српске, 2007).

${ }^{48}$ Ibid, 134.

49 Бранка Кулић, Новосадске дрворезбарске радионице. 
уметничких радионица које се баве израдом крстова још увек постоје неканонски израђени крстови који су у свакодневној богослужбеној употреби деценијама иза нас али и данас. ${ }^{50}$ Поред тога савремена црквена уметности дрворезбарства стоји пред новим изазовима машинске обраде коју не треба у потпуности одбацити али је и не злоупотребљавати. Потпуно је јасно да је уметник дрворезбар незамењив у стварању савременог уметничког дела, као и у процесу рестурације културног наслеђа које су нам оставиле генерације предака. Савремено дрворезарство на нашим просторима и у свету, „силом прилика", у великој мери почива на машинској изради црквеног мобилијара и богослужбених предмета. ${ }^{51}$ Широка употреба предмета црквене уметности који се машински израђују су преплавила Србију али и свет. Чинећи наклон овој масовној производњи, окрећемо леђа и потпуно занемарујемо институције и појединце који добивши уметничке таленте имају вољу да својим радом очувају традиционалне вредности српског народа и стварају савремену црквену уметност на којој ће се градити генерецаије које долазе. Традиционално дрворзабрство се очувало у ретким приватним радионицама или професионалним радионицама које су саставни део институција чија је примарна делатност заштита културног наслеђа. Препознати важност очувања уметности дрворезбарства у савременом свету је привилегија ретких самосталних уметника или изабраних појединаца запослених у институцијам културе чијим залагањем Србија ствара али и чува и обнавља богату културну баштину свог народа. Поље деловања радионица при оваквим институцијама досеже ван граница наше земље до Свете Горе, Румуније, Мађарске, БиХ,... ${ }^{52}$ Рад у племенитом металу и филиграну је са дрворезбарством у нераскидивој вези од првих уметничких дела које ова уметност памти. Рад у племени-

\footnotetext{
${ }^{50}$ Нпр. честе су представе Бога Оца на ручним крстовима који су данас у употреби.

${ }^{51}$ Доступност основног, а потом и академског образовања готово да не постоји како у Србији тако и шире.

52 Покрајнски Завод за заштиту СК у Петроварадину је једна од таквих установа културе Републике Србије .
} 
том металу данас је у највећој мери очуван захваљујући малом броју самосталних ликовних уметника-вајара који стварају у оквиру самосталних радионица благословом надлежних Архијереја СПЦ. Стваралаштвом ови уметници препознати од Цркве, савремену црквену уметност потврђују за достојног наследника вековима стваране уметности нашег народа. ${ }^{53}$

$$
* * *
$$

Знак крста присутан је још у текстовима Старог завета. Налазимо га у књигама пророка Мојсија, Исаије, Соломона. Крст у прво време означава казну и срамоту, а потом победу и Васкрсење. Уметност већ у првим вековима изузетно успешно својим средствима открива снагу Крста, првенствено у архитектури, зидном живопису, мозаичкој уметности а потом и примењеној уметности дрворезбарству и филиграну. Широка примена различитих типова крстова и богатство иконографских решења у црквеној уметности забележена је кроз векове уназад до данас. Проблеми који се тичу образовања наручилаца дела црквене уметности као и стручности и талента оних који се баве црквеном уметношћу треба да су у ширем контексту сагледани, како не би дошло до потпуне деградације црквене уметности дрворезбарства, рада у племенитом металу и др.

\section{Литература:}

Bovini, Giuseppe. Mosaici de S. Apollinare Nuovo di Ravenna: Il Ciclo Cristologico. Firenze: Arnaud, 1958.

Герке, Фридрих. Касна антика и рано хришћанство. Нови Сад: Братство и јединство, 1973.

Дамаскин, Јован Свети. „Апологетска слова против опадача Светих Икона". У Седми васељенски сабор: юегов одјек у ирквеној уметности : одабрана документа. Ур. Радомир По-

${ }^{53}$ Издваја се самостални уметник академски вајар Немања Радојичић из Ваљева, као и Филигранско-кујунџијска радионица за израду уметничких предмета од племенитих метала «Филигран Покимица» Краљево - Србија... 
повић, 61-87. Београд: Академија Срспске православне цркве за уметности и консервацију, 2012.

Јанићијевић, Горан. Хришћанска уметност и античке парадигме. Београд: Академија Срспске православне цркве за уметности и консервацију, 2012.

Языкова, Ирина. Богословие иконы. Москва: Общедоступный Православный Университет, 1995.

Кораћ, Војислав и Марица Шупут. Архитектура византијског света. Београд: Завод за уџбенике, 2005.

Кулић, Бранка. Новосадске дрворезбарске радионице. Нови Сад: Галерија Матице српске, 2007.

Mazzeti, Mario. La Basilica di Sant Apollinare in Classe. Cittta del Vaticano: Pontificio Istituto di Archeologia, 1954.

Mango, Cyril. Architettura Bizantina. Milano: Mondadori Electa, 1978.

Марјановић- Вујовић, Гордана. Крстови од VI-XII века из збирке Народног Музеја. Београд: Народни музеј, 1977.

Миловановић, Душан. Крстови: (од 5. века до 1993. године): типологија и историјско стилски развој збирке крстова Музеја применене уметности из Београда. Београд: Музеј примењене уметности, 1993.

Мирковић, Лазар. Иконографске студије. Нови Сад: Матица српска, 1974.

Поповић, Радомир. Седми васељенски сабор: његов одјек у ирквеној уметности: одабрана документа. Београд: Академија Срспске православне цркве за уметности и консервацију, 2012.

Пурић, Јован. Богословље и педагогика Св. Јована Златоустог. Књ. 3, Београд: Верско добротворно старатељство Архиепископије београдско-карловачке, 2011.

Радојковић, Бојана. Уметничка обрада метала. Београд: Музеј примењене уметности, 1953.

Радојковић, Бојана. Српско златарство XVI и XVII века. Нови Сад: Матица српска, 1966.

Велики православни богословски енциклопедијски речник. Том 2, Нови Сад: Православна реч, 2000. 
Радојчић, Светозар. „Бронзани крстови - реликвијари из раног средњег века у београдским збиркама". У Одабрани чланци и студије: 1933-1978. Београд: „Југославија”, Нови Сад: Матица Српска, 1982.

Сандо, Драгомир. Богослужење као основа образовања и васпитања у иркви. Београд: Глобосино 2009.

Strzygowski, Joyef. O razvitku starohrvatske umetnosti: prilog otkriću sjeverno-evropske umjetnosti. Zagreb: Matica hrvatska, 1927.

Томић, Оливер. Геометријски симболизам у примордијалној традицији. Београд: Математичи институт САНУ, 2021. // miteam.mi.sanu.ac.rs/asset/fKxCZkJ5efhtrwCbT. аудио снимак (приступљено 20.9. 2021).

Трифуновић, Лазар и Ђурђе Бошковић. Стара култура y Ђердany: Anciennes cultures du Đerdap. Београд: Галерија Српске академије наука и уметности, 1969.

The Glory of Byzantium Art and culture of the Middle Byzantian era A.D.843-1261. New York: The Metropolitan Museum of Art, 1997.

Ћоровић-Љубинковић, Мирјана. Средњевековни дуборез у источним областима Југославије. Београд: Научно дело, 1965.

Шакота, Мирјана. Ризнице манастира у Србији. Нови Сад: Платонеум, 2017.

Шакота, Мирјана. Ризница Манастира Бање код Прибоја. Нови Сад: Платонеум, 2018. 


\title{
THE DIVINE MIGHTNESS OF THE LORD AND ITS REFLECTION IN THE ART OF WOOD CARVING
}

\author{
Jovan Ćeranić \\ The Provincial Institute for the Protection of Cultural Monuments, \\ Petrovaradin \\ e-mail: jovanceranic@gmail.com
}

\begin{abstract}
Summary: The Cross as a sign and symbol remembers the paleolithic, neolithic, iron age and mycenaean culture. The punishment of crucifixion is known in ancient times, but also in the decades before Christ in Egypt. In the beginning, cross is simpler shape was made only of a vertical. The more complex cross of two trees, crux commisa, vertical and horizontal, appears in the time immediately before Christ coming into the world and his suffering on the cross. With the crucifixion of the Lord Jesus Christ, the cross gained a new meaning, becomes an instrument of victory over sin and death, the strength and power of Orthodox Christians in all ages. The cross as a concept and symbol has been present in the Church since the first centuries of Christianity.

In addition to theologians, the study of crosses was started in the 19th century by archaeologists, art historians. During the 20th century, research was mostly continuously continued, and a step further was the constitution of a new science - staurography. Its wide use function, rich typology and variety of art forms have been noticed. The iconography of the cross has been formed since the 6th century, and the most developed representations are preserved on the wood-carved crosses of the Mount Athos workshops of the XVI, XVII and XVIII centuries. Woodcarving, one of the oldest and most widespread arts, is today largely neglected and suppressed by the modern machine-making of church furniture and other objects of Church art.
\end{abstract}

Key words: Cross, Symbol, Church art, Iconography, Woodcarving. 